\title{
Огурец в открытом грунте: оптимальные способы выращивания
}

\section{А.В. Константинович, В.И. Терехова}

Представлены результаты исследований влияния способов выращивания гибридов огурца в условиях открытого грунта в Ярославской области на урожайность и качество продукции. Установлено достоверное превышение урожайности и выхода товарной продукции при выращивании рассадным способом на шпалере.

Ключевые слова: гибриды огурца, открытый грунт, урожайность, товарность продукции, способы выращивания.

B открытом грунте огурец традиционно выращивают на открытых грядах в расстил. Но в последнее годы возросли требования к качеству продукции, поступающей из отрытого грунта, что повлияло на внедрение промышленной технологии шпалерной культуры огурца, которая позволяет не только повысить урожайность, но и товарное качество продукции, обеспечивая получение ровных, равномерно окрашенных, свободных от грунта плодов $[1,5]$.

Цель исследований - оценить урожайность и выход товарной продукции гибридов огурца в зависимости от способа выращивания (рассада, прямой посев, шпалера, в расстил) в условиях открытого грунта.

Исследования проводили в 20162018 годах в условиях Переславского района Ярославской области на территории КХ Берестнева А.В. Почва на опытном участке серая лесная окультуренная среднесуглинистая (содержание $\mathrm{N}-\mathrm{NO}_{3}-8,6$ мг/кг, $\mathrm{pH}_{\mathrm{kcl}} 6,9, \mathrm{P}_{2} \mathrm{O}_{5}$ - $180 \mathrm{Mг} / \mathrm{Кг,} \mathrm{K}_{2} \mathrm{O}-257 \mathrm{Mг} / \mathrm{Кг)}$.

Объекты исследований: партенокарпические гибриды огурца, $\mathrm{F}_{1}$ Каролина, $F_{1}$ Атос, $F_{1}$ Маша

$F_{1}$ Каролина. Период от всходов до начала плодоношения 40-45 суток. Растение высокорослое с хорошей регенерационной способностью. Плод цилиндрический, темно-зеленый, крупнобугорчатый, белошипый, длиной 8-11 см.

$F_{1}$ Атос. Период от всходов до начала плодоношения 38-40 суток. Растение высокорослое. Формирует в узлах от 5- до 7 плодов Плод цилиндрический, темно-зеленый, мелкобугорчатый, белошипый, длиной 6-9 см.

$F_{1}$ Маша. Период от всходов до начала плодоношения 38-40 суток.
Растение высокорослое. Формирует в узлах до 5 плодов Плод цилиндрический, темно-зеленый, крупнобугорчатый, белошипый, длиной 7-10 см [2].

Варианты опыта: фактор А: выращивание на шпалере (высота 150 см) и в расстил, фактор Б: рассадный способ и прямой посев семян в грунт.

Посев семян для получения рассады проводили во второй декаде мая в кассеты с объемом ячейки $180 \mathrm{~cm}^{3}$, возраст рассады 20 суток. Прямой посев проводили в третьей декаде мая. Всходы отмечали на 4-5 сутки при разных способах посева.

Схема размещения растений при выращивании на шпалере 140+70×40 см, в расстил - 140+70×20 см [3].

Площадь опытного участка - 800

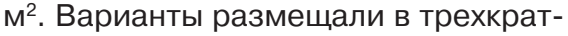
ной повторности по двадцать растений в каждой. Площадь опытной делянки $-8,4 \mathrm{M}^{2}[4]$.

\begin{tabular}{|c|c|c|c|c|c|}
\hline $\begin{array}{l}\text { Урожайнос } \\
\text { (среднее з }\end{array}$ & $\begin{array}{l}\text { гь гибридо } \\
\text { 2016-2018 }\end{array}$ & $\begin{array}{l}\text { огурца в } \\
\text { ды) }\end{array}$ & висимости от & способа & щивания, \\
\hline Способ вы & оащивания & Гибрид $F_{1}$ & $\begin{array}{c}\text { Общая } \\
\text { урожайность, } \\
\text { т/га }\end{array}$ & $\begin{array}{c}\text { Ранняя } \\
\text { урожайность, } \\
\%\end{array}$ & $\begin{array}{c}\text { Выход } \\
\text { товарной } \\
\text { продукции, \% }\end{array}$ \\
\hline & & Каролина & 73,5 & 10,2 & 96,7 \\
\hline & Рассада & Атос & 76,4 & 9,8 & 96,8 \\
\hline & & Маша & 82,2 & 12,2 & 96,8 \\
\hline шпалере & & Каролина & 61,7 & 14,2 & 94,3 \\
\hline & Прямой & Атос & 66,8 & 10,9 & 96,4 \\
\hline & & Маша & 67,8 & 14,8 & 96,5 \\
\hline & & Каролина & 64,4 & 8,4 & 74,4 \\
\hline & Рассада & Атос & 67,6 & 7,6 & 76,7 \\
\hline$\Omega_{1}$ & & Маша & 74,2 & 8,9 & 79,2 \\
\hline В расСТЛ & & Каролина & 51,4 & 7,4 & 74,8 \\
\hline & Прямой & Атос & 52,6 & 6,9 & 75,9 \\
\hline & & Маша & 58,8 & 6,8 & 78,8 \\
\hline $\mathrm{HCP}_{05}$ & & & 13,1 & 1,8 & 10,4 \\
\hline
\end{tabular}

По результатам фенологических наблюдений установлено, что наступление фаз фенологического развития у исследуемых гибридов различалось в зависимости от климатических условий года. Однако период от всходов до начала плодоношения при прямом посеве и выращивании на шпалере в среднем на пять суток меньше, чем у растений при рассадном способе и выращивании в расстил. Первую продукцию учитывали при высадке рассадой на 45-46 сутки от всходов, при прямом посеве на 40 сутки.

Учет урожайности проводили весовым методом, при сборе зеленцов каждые 1-2 дня. Данные по урожайности приведены в таблице.

В результате испытаний гибридов огурца при выращивании в условиях открытого грунта общая урожайность составляла от 64,4 ( $\mathrm{F}_{1}$ Каролина) до 82,2 т/га ( $F_{1}$ Маша) при выращивании рассадным способом и от 51,4 ( $F_{1}$ Каролина) до 67,8 т/ га $\left(F_{1}\right.$ Маша) при прямом посеве семян в грунт. Отмечено более позднее вступление в плодоношение растений огурца при выращивании в расстил, что повлияло на поступление ранней продукции. 
При оценке структуры урожайности отметили более высокий выход товарной продукции при выращивании на шпалере от 94,3 до 96,8\%, в сравнении с выращиванием в расстил, где выход товарной продукции составил от $74,4 \%$ до 79,2\%, так как плоды соприкасаются с грунтом, неравномерно освещены, а также подвержены воздействию повышенной влажности.

Выводы. Для выращивания культуры огурца в условиях открытого грунта Ярославской области для обеспечения стабильно высокой урожайности и качества продукции целесообразно использовать рассадный способ и ведение культуры на шпалере.

\section{Библиографический список}

1.Шпалерный способ выращивания огурца в открытом грунте [Электронный ресурc]. URL:http://www. agroyug.ru/news/id-17469 Дата обращения 21.01.2019 2.Государственный реестр селекционных достижений, допущенных к использованию [Электронный ресурс]. URL:https://reestr.gossort.com/reestr/search Дата обращения 21.01.2019

3.Портянкин А.Е., Шамшина А.В. Огурец: От посева до урожая / Под ред. доктора с.-х. наук, проф. С.Ф. Гавриша. М.: НП «НИНОЗГ», ЗАО «Фитон+». 2010. 400 с.

4.Литвинов С.С. Методика полевого опыта в овощеводстве. М.: Россельхозакадемия, 2011. 648 с

5.Борисов В.А. Качество и лежкость овощей / В.А. Борисов, С.С. Литвинов, А.В. Романова. М.: ГНУ ВНИИО, 2003. 625 с.

\section{Об авторах}

\section{Константинович Анастасия}

Владимировна, канд. с.-х. наук, доцент, зав. кафедрой овощеводства.

E-mail: rumexred@gmail.com

Терехова Вера Ивановна, канд. с.х. наук, доцент кафедры овощеводства. E-mail: vterechova@yandex.ru ФГБОУ ВО РГАУ-МСХА ИменИ К.А. Тимирязева

Cucumber in the open ground: optimal growing methods

A.V. Konstantinovich, $P h D$, associate

professor, head of vegetable growing chair. E-mail: rumexred@gmail.com

V.I. Terechova, $P h D$, associate professor vegetable growing chair.

E-mail:vterechova@yandex.ru Russian State Agrarian University - Moscow Timiryazev Agricultural Academy named after K.A. Timiryazev

Summary. The results of studies of the influence of methods of growing cucumber in open ground on yield and product quality are presented. A significant excess of yield and yield of commercial products when growing seedlings on the trellis is ascertained. The characteristics of hybrids suitable for cultivation for both the hobby and professional market is given.

Keywords: cucumber hybrids, open ground, yield, marketability of products, growing methods.

\section{Государство поддержит}

Господдержка ставропольских производителей овощей и семян увеличена в 1,5 раза.

В Минсельхозе Ставропольского края состоялся круглый стол, посвященный проблемам и перспективам развития семян овощных культур. Сегодня потребность С. - х. организаций края и страны на 75-80\% зависит от поставок семян овощных культур из-за рубежа.

В ходе мероприятия была достигнута договоренность о создании рабочей группы для обобщения и выработки поступивших предложений по данной теме.

«По итогам 2018 года с.- х. товаропроизводителями Ставрополья произведено 142,9 тыс. т овощей открытого грунта и 115,6 тыс. т картофеля. В рамках оказания несвязанной поддержки субсидии были предоставлены 140 с.- х. товаропроизводителям в общей сумме более 129 млн р. В текущем году на поддержку производителей овощей и семян с.- х. культур Ставропольского края предусмотрено 209,3 млн р., что в 1,5 раза выше уровня 2017 года. Ожидаемый размер ставки в зависимости от количества заявителей составит порядка 20-25 тыс. р. на 1 га посевной площади овощей открытого грунта»,- сообщил заместитель министра сельского хозяйства Ставропольского края Андрей Олейников.

Участники совещания также подчеркнули особую значимость разработки Федеральной государственной программы «Развитие производства семян, овощных культур и картофеля в РФ на 2020-2025 гг.».

\section{Источник: www.mcx.ru}

\section{Больше витаминов янтарному краю}

Калининградская область увеличила мощности для производства овощей.

В Калининградской области состоялось открытие второй очереди тепличного комплекса ООО «Орбита-Агро». В мероприятии принял участие губернатор Антон Алиханов.

Высокотехнологичный круглогодичный тепличный комплекс ориентирован на выращивание томатов, огурцов, зеленных культур. С его вводом в эксплуатацию предприятие почти в два раза увеличило свои производственные мощности. Они составили 6,1 га. Таким образом, общая площадь теплиц круглогодичного использования в Калининградской области достигла 8,8 га.

Новый комплекс построен по современным технологиям с использованием оборудования ведущих производителей. Промышленные теплицы оснащены передовыми системами отопления и вентиляции для поддержания заданного микроклимата, автоматическим (в том числе капельным) поливом. Общий объем инвестиций в проект составил более 327 млн р. Прогнозируемый объем производства овощей на «Орбита-Агро» с вводом в строй второй очереди к концу 2019 года превысит 2000 т.

«Аграрный сектор является для нас приоритетным и будет в центре внимания еще долгое время, потому что нам есть, куда расти. Мы еще далеки от удовлетворения потребностей области собственной овощной продукцией. Этот проект получил очень серьезную федеральную поддержку на финансирование строительства. Областное правительство тоже вложило субсидии в объект. На этом прошу не останавливаться. Мы готовы поддерживать подобные проекты и дальше. Места хватит всем, не говоря уже о том, что мы вполне можем двигаться на рынки других субъектов и за рубеж»,- сказал Антон Алиханов.

Губернатор особое внимание обратил на запуск салатной линии, которая позволила расширить ассортимент овощей горшечными зеленными культурами, в том числе салатами, укропом, луком, петрушкой, руколой, базиликом, шпинатом.

«У региона огромные перспективы в сфере овощеводства. Наше внимание будет постоянно нацелено на достижение определенных показателей продовольственной безопасности, обеспеченности жителей области именно овощными культурами. В Гвардейском округе построено совершенно уникальное предприятие, где мы будем получать более полутора тысяч тонн овощей в год. Причем мы увидим здесь урожайность огурцов не менее 56 килограммов с квадратного метра, а томатов - не менее 48 килограммов. Это практически в два раза больше, чем на аналогичных комплексах области, которые уже работают круглогодично»,- подчеркнула министр сельского хозяйства Наталья Шевцова.

Отметим, первую очередь тепличного комплекса для выращивания огурцов и томатов ООО «Орбита-Агро» ввела в строй в 2014 году. 